\title{
Contents, Vol. 7, 1975
}

\section{Contents}

Bellhorn, R. W. and Bellhorn, Margaret S. (Bronx, N. Y.): The Avian Pecten. I. Fluorescein Permeability 1

Murata, T. and Taura, Yoko (Kumamoto): Study of Trace Metallic Elements in the Lens 8

Ono, S.; Hirano, H., and Obara, K. (Morioka): In vitro Studies on the Metabolism of Cortisol-4-[14C] in the Lenses of Rats during Maturation 15

Worgul, B.V. and Rothstein, H. (Burlington), Vt.: Radiation Cataract and Mitosis 21

Refojo, M. F. and Thomas, D. A. (Boston, Mass.): Sustained Release of Antibiotics from Scleral Buckling Materials. I. Gelatin and Solid Silicone Rubber 33 Sayegh, F. and Weigelin, E. (Bonn): Blood Pressure, Cerebral Circulation and Intra ocular Pressure in Cushing's Syndrome 45

Henkind P. and Szalay, Jeanne (New York, N. Y.): Intralenticular Vessels. Clinico-Ultrastructure Correlation 52

Kaskel, D.; Schedtler, Ch.-M.; Hockwin, O., and Cioli, S. (Bonn): Localization of Glycogen in Lenses of Different Species, Demonstrated by Histochemical Methods 65

Schütte, E.; Werner, R.D., and Reim, M. (Marburg/Lahn): Intravenous Fructose Infusion 73

Francois, J.; Hanssens, M.; Teuchy, H., and Sebruyns, M. (Ghent): Ultrastructural Findings in Corneal Macular Dystrophy (Groenouw II Type) 80

Riebel, O.; Lang, B. A., and Preisová, J. (Brno): Clinical and Biochemical Study of Subretinal Fluid Globulins Examined by Disc Electrophoresis 99

Honda, Y. and Dawson, W.W. (St. Louis, Mo./Gainesville, Fla.): Botulinum Into xication of Isolated Retinas 108

Henley, W.L.; Okas, S., and Leopold, I.H. (New York, N. Y.): Leukocyte Migra tion Inhibition by Individual Homologus Antigens in Uveitis 118 Henley, W.L.; Okas, S., and Leopold, I.H. (New York, N.Y.): Leukozyte Migra tion Inhibition by Choroid and Retina in Retinal Detachment 129 Basta, Leila ; Bourne, W. M., and Blodi, F. C. (Iowa City, Iowa): Effect of Various Stages of Cryopreservation on the Viability of Corneal Endothelium. A Histo chemical Study 133

Dreifus, M. and Wobmann, P. (Zurich): Influence of Soft Contact Lens Solutions on Rabbit Corneae. A Clinical and Electron Microscopical Study 140 Ronchi, Lucia and Molesini, G. (Florence): Depth of Focus in Peripheral Vision 152 Unakar, N.J.; Binder, L.I.; Reddan, J.R. and Harding, C.V., jr. (Rochester Mich./Detroit Mich.): Histochemical Localization of Acid Phosphatase in the Injured Rabbit Lens 158 
Martenet, Anne-Catherine (Zurich): The Treatment of Experimental Deep Herpes Simplex Keratitis with Ethyl-Deoxy-Uridine and Iodo-Deoxy-Cytidine ... 170

Tokumaru, T. and Fromer, C. (New York N. Y.): Herpetic Epithelial Keratitis: Conditions for Photocoagulation Treatment by Argon Laser as Analyzed by Binding of Dye- and Radiolabeled Antiherpes y-globulin onto Corneal Ulcers 181

Puig-Parellada, P.; Planas, J.M., and Puig-Muset, P. (Barcelona): Imidazole

Inhibits the Rise in Intraocular Pressure Induced by Arachidonic Acid 189

Contents

III

Meretoja, J. and Tarkkanen, A. (Helsinki): Pseudoexfoliation Syndrome in Familial Systemic Amyloidosis with Lattice Corneal Dystrophy (With 1 Colour Plate) 194

Ikeda, A. and Maisel, H. (Detroit, Mich.): Immuno-Electronmicroscopic Study of Chick Lens Proteins 204

Dahl, H.D. and Borchard, U. (Cologne): Experimental Siderosis of the Isolated

Retina Induced by Fe(III) Solutions 209

Augusteyn, R. C. (Parkville): Distribution of Fluorescence in the Human Cataractous Lens 217

Gruber, P. (Zurich): Antibody Formation against Horseradish Peroxidase in Choroidal Plasma Cells in the Rabbit. Light and Electron Microscopic Study 225

Krogh, E. (Copenhagen): The Corneofundal Potential of the Rabbit Eye. An Assess ment Based on Thévenin's Theorem 236

Hoose Madeline C. van and Leaders, F.E. (Fort Worth, Tex.): A Simple Method for Evaluation of Ocular Decongestants 246

Bellhorn, R. W.; Bellhorn, Margaret B.; Swarm R. L., and Impellizzeri C. W. (Bronx, N. Y.i Nutley, N. Y.): Hereditary Tapetal Abnormality in the Beagle . 250 Francois, J. and Victoria-Troncoso, V. (Ghent): Histopathogenic Study of the Macular Dystrophy of the Cornea. Fehr's Dystrophy or Groenouw's Type II. (With 1 Colour Plate) 261

Joffe, S. N. (Cape Town): Incidence of Postoperative Deep Vein Thrombosis in Ophthalmology 270

Henley, W.L.; Okas, S.; Furman, M., and Leopold, I.H. (New York, N.Y.): Immunologic and Protein Study of Human and Animal Corneas 274 Korte, Inge; Hockwin, O.; Tullius, H.; Diederich, D.; Steidtel, C.-U., and Scholl, W. (Bonn): Studies on the Influence of l-Hydroxy-Pyrido-(3,2a)-5-Phenoxazone-3-Carboxylic Acid on the Carbohydrate Metabolism of the Lens 282

Amemiya, T. (Kyoto): Cilia in the Retinal Pigment Epithelium of the Adult Rat .. 292

Brettschneider, I.; Praus, R.; Krejcí, L., and Hayránek, M. (Prague): Intra ocular Penetration of Bacitracin and Polymixin B after Administration by Means of Hydrophilic Gel Contact Lenses 296

Stárka. L.; Kolín, J., and Obenberger, J. (Prague): Cortisol Levels in Human Aqueous Humour and Blood Plasma 303

Lang, B. A.; Riebel, O., and Preisová, J. (Brno): Disc Electrophoresis of Globulin Fractions of Aqueous Humour in Patients with Retinal Detachment 308 Johansson, G.; Huhtala, A., and Saari, M. (Helsinki/Oulu): Observation on the Nerves of the Cat Iris after Denervation of the Ophthalmic Division of the Trigeminal Nerve 315 
Francois, J.; Hanssens, M., and Teuchy, H. (Gent): Ultrastructural Changes in Lattice Dystrophy of the Cornea 321

Tokumaru, T.; Shimizu, Y., and Sabety, E. (New York, N. Y.): Herpetic Epithelial Keratitis: a Radioassay Evaluation of the Host's Humoral and Cellular Respon siveness $\quad 345$

Huhtala, A.; Johansson, G., and Saari, M. (Oulu): Myelinated Nerves of Guinea

Pig Iris after Denervation of the Ophthalmic Division of the Trigeminal Nerve 354

Obenberger, J. (Prague): Paper Strips and Rings as Simple Tools for Standardization

of Experimental Eye Injuries 363

IV

\section{Contents}

Langham, M.E.; Frentzel-Beyme, R.R., andTRAUB, Z.-D. (Baltimore, Md./Hamburg/ Monrovia): Intraocular Pressure and Onchocerciasis Infection in Liberia 368 Vassileva, P. (Sofia): Studies on Some Dehydrogenases in Experimental Retinal Ischaemia 381

Sayegh, F. and Weigelin, E. (Bonn): Intraocular Pressure in Cushing's Syndrome 390 Honda, Y. and Nagata, M. (Kyoto): A Neurological Side Effect of Cephaloridine:

Enhancement of the Electroretinogram 395

Glickstein, M.; Cameron, J., and Yanoff, M. (Philadelphia, Pa.): In vitro Studies

of Corneal Wound Healing in Dogs 401

Kaskel, D.; Scholz, R.; Hockwin, O., and Ziesmer, W. (Bonn): Composition of Aqueous Humour and Lens After Carotid Ligation 409

Maisel, H.; Lieska, N., and Alcalá, J. (Detroit, Mich.): Effect of Urea on Chick

Lens Proteins 416

Francois, J. and Victoria-Troncoso, V. (Ghent): Histopathogenic Study of the

Lattice Dystrophy of the Cornea (with 2 Colour Plates) 420

Laszczyk, Wieslawa A. (Warsaw): Development of Cataract as the Effect of Glutamic Acid Administration to Chick Embryo 432

Korte, Inge; Hockwin, O.; Tullius, H., and Diederich, D. (Bonn): Effect of 1Hydroxypyrido-(3,2a)-5-Phenoxazone-3-Carboxylic Acid on the Reduced Coenzymes NADH and NADPH 440

Ronchi, Lucia and Fontana, A. (Florence): Methods Currently Adopted for Testing Sight 447

Praus, R. and Brettschneider, I. (Prague): Glycosaminoglycans in Embryonic and Postnatal Human Cornea 452

Refojo, M. F. (Boston, Mass.): Sustained Release of Antibiotics from Scleral Buck ling Materials. II. Silicone Sponge 459

Short Communication

Ono, S.; Hirano, H., and Obara, K. (Morioka): In vitro Effects of Sulphydryl Agents on the Cortisol-Binding Capacity of the Rat Lens 126

Announcements 320,470

Subject Index 471

Author Index 476 